Article

\title{
Experimental Assessment of the Influence of Fish Passage Geometry Parameters on Downstream Migrating Atlantic Salmon (Salmo salar) Smolts Behavior
}

\author{
Sebastien Erpicum ${ }^{1, *(D)}$, Vasileios Kitsikoudis ${ }^{2}$, Pierre Archambeau ${ }^{1}$ (D) Benjamin Dewals ${ }^{1}$ (D) \\ and Michel Pirotton ${ }^{1}(\mathbb{D})$
}

Citation: Erpicum, S.; Kitsikoudis, V.; Archambeau, P.; Dewals, B.; Pirotton, M. Experimental Assessment of the Influence of Fish Passage Geometry Parameters on Downstream Migrating Atlantic Salmon (Salmo salar) Smolts Behavior. Water 2022, 14, 616. https://doi.org/10.3390/ w14040616

Academic Editors: Ismail Albayrak, Laurent David and Ana Margarida Ferreira Teixeira da Silva

Received: 29 December 2021 Accepted: 15 February 2022 Published: 17 February 2022

Publisher's Note: MDPI stays neutral with regard to jurisdictional claims in published maps and institutional affiliations.

Copyright: (C) 2022 by the authors. Licensee MDPI, Basel, Switzerland. This article is an open access article distributed under the terms and conditions of the Creative Commons Attribution (CC BY) license (https:/ / creativecommons.org/licenses/by/ $4.0 /)$.
1 Research Unit Urban \& Environmental Engineering (UEE), Hydraulics in Environmental and Civil Engineering (HECE), University of Liège, 4000 Liège, Belgium; pierre.archambeau@uliege.be (P.A.); b.dewals@uliege.be (B.D.); michel.pirotton@uliege.be (M.P.)

2 Water Engineering and Management, Faculty of Engineering Technology, University of Twente, 7500 AE Enschede, The Netherlands; v.kitsikoudis@utwente.nl

* Correspondence: s.erpicum@uliege.be

\begin{abstract}
The fragmentation of rivers caused by the construction of dams and weirs disturbs fish migration and poses a threat to fish populations and aquatic biodiversity. Fish passages around hydraulic structures aim to restore river connectivity; however, the effective design of fish passages is a challenging problem that depends on several processes. The present experimental study investigated how the characteristics of a trash rack at the entrance of a fish passage for downstream migration affects fish behavior and subsequently the effectiveness of the fish passage. A series of experiments was carried out to systematically analyze the behavior of Atlantic salmon smolts in a flume with two outlets featuring the same 1:1 physical model of the entrance of a downstream passage with or without a trash rack. The parameters that were tested were the spacing of the vertical round bars of the trash rack, the location of the trash rack at the fish passage, and the velocity gradient at the entrance of the passage. Aggregated results showed that only $34 \%$ of the fish selected the outlet with a trash rack to exit the flume while $66 \%$ preferred the unobstructed outlet. More fish swam through the outlet with the trash rack when the spacing of the vertical bars increased from $10 \mathrm{~cm}$ to $20 \mathrm{~cm}$ and when the rack was placed in the higher velocity region compared to the lower velocity one. These results show that a trash rack acts as an obstacle to Atlantic salmon smolts passing through a downstream passage. When possible, trash racks should be avoided at the entrance of downstream fish passages.
\end{abstract}

Keywords: Atlantic salmon; ecohydraulics; experimental hydraulics; fish migration; fish passage; hydraulic structures

\section{Introduction}

Dams and weirs in rivers are vital parts of water management, navigation and discharge regulation, e.g., [1]. However, the construction of such hydraulic structures leads to river fragmentation, which can decrease the seasonal discharge variability and affect the natural flow dynamics in certain segments of the river [2]. These structures also have a severe impact on river ecology with potentially detrimental effects on fish populations $[3,4]$. One of the most important adverse effects of dams and weirs is the fact that they hinder fish migration to and from spawning grounds and subsequently threaten the aquatic biodiversity. This problem has long been acknowledged, with the first science-based efforts to facilitate upstream migration of fish through or around hydraulic structures noted in the beginning of the previous century, while some more crude attempts were noted even earlier [5]. However, the fish passage efficiency, both for upstream and downstream migration, is still not at the desired level [6]. Currently, the design and construction of fish 
passages require an interdisciplinary approach, with inputs from biology and hydraulic experts [7]. While there have been successful examples of upstream fish passages [7], the design of downstream fish passages for juvenile fish, such as salmon smolts [8], is still a challenging task [9-12]. The complexities of downstream fish passages can be attributed to the swimming behavior of the migrating fish in certain hydrodynamic conditions [13], the fish capability to find and use the downstream passage within a short amount of time [14], and whether or not the fish will be attracted by the turbines and get injured in cases of dams for hydroelectricity [15,16]. In hydroelectric dams, the guidance screens [17] and the trash diverters [18] also affect the design of an efficient downstream fish passage.

This study lies in a project aiming at restoring downstream connectivity in the Meuse River by implementing passage solutions for European eels (Anguilla anguilla) and Atlantic salmon smolts (Salmo salar) at six hydropower plants (www.life4fish.be, accessed on 28 December 2021). In this framework, the construction of downstream passages dedicated to salmon smolts was identified as a relevant solution (in the scope of the project, repulsive barriers, temporary shut off of the power plants coupled to a migration prediction model, and flap gates opening at dams are other alternatives considered). In the design phase of the downstream passage, specific questions appeared regarding where and how a trash rack should be placed to avoid blocking of the passage by floating debris while limiting impact on fish attraction. To address these specific questions, a series of experimental tests was deemed necessary.

In situ testing and fish monitoring with field measurements in real hydraulic structures is a laborious and costly task, which is also limited to the occurring flow conditions. As a result, only a few different parameters can be examined in such studies. On the other hand, laboratory physical modeling provides the means for more systematic analyses with reasonable cost and time investment, while perfectly controlling flow conditions. Experiments with live fish in physical models have provided useful information about, for example, the fish guidance efficiency of louvers and modified angled bar racks for five different fish species [19], curved-bar rack bypass systems for several European fish species [20], the effectiveness of bubble barriers with and without an optical stimuli on guidance of Atlantic salmon for downstream migration [21], and the effect of a light source in combination with a flow velocity gradient on downstream migration of brown trout (Salmo trutta) [22]. While there have been several experimental studies observing and monitoring the response of fish to different hydraulic structures and flow conditions [23-26], the effect of trash racks that prevent the blockage of downstream passages from floating debris lacks systematic investigation. The research objective of this study was to examine how the selection of downstream route by Atlantic salmon smolts is affected by trash rack geometry and location, with the assumption that any obstacle in the flow has a repelling effect.

\section{Experimental Setup and Methods}

\subsection{Experimental Facility and Instrumentation}

The focus of this experimental study is on downstream migrating Atlantic salmon smolts and how they react to different geometrical arrangements of a downstream passage. To this end, several flume experiments in 1:1 scale were carried out at the Engineering Hydraulics Laboratory at the University of Liege in Belgium with varied geometries of a fish passage inlet.

The experimental setup (Figure 1) consisted of a straight horizontal flume, $5.8 \mathrm{~m}$ long and $0.80 \mathrm{~m}$ wide, with a fish passage inlet at its downstream end. Water was pumped into a $1.8 \mathrm{~m}$ long and $1.6 \mathrm{~m}$ wide reservoir connected to the upstream end of the flume. The flow from the upstream reservoir entered the flume through a constriction with a screen wall that smoothened the flow. At the flume outlet, fish passage was made of a ramp at constant slope where flow depth decreased in order to increase gradually the flow velocity. After the ramp, there was a horizontal broad-crested weir to control flow conditions in the 
flume and then a vertical chute. After the chute, flow discharged into two downstream reservoirs where water level was controlled to be just below the broad crest elevation.

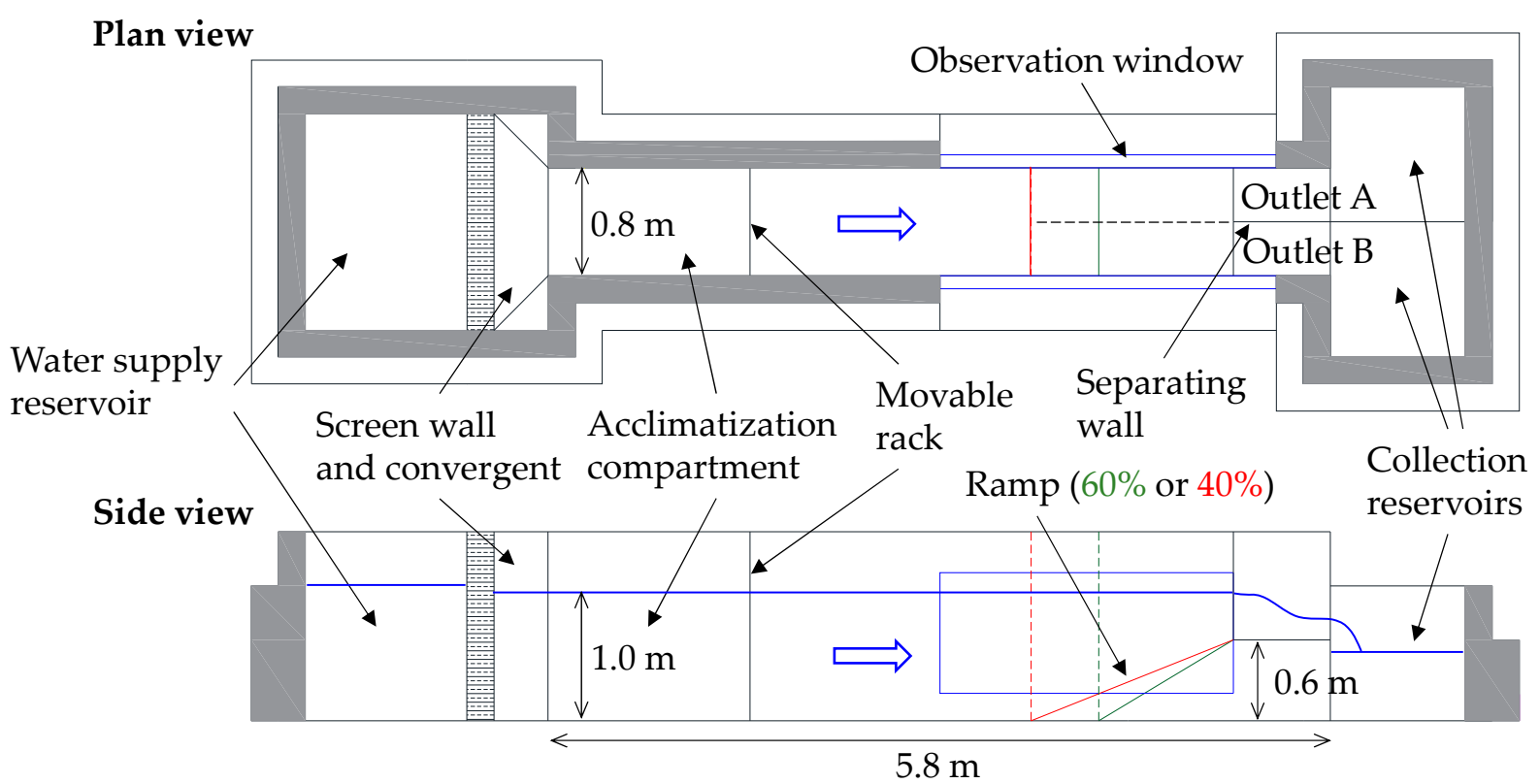

Figure 1. Experimental flume geometry and main dimensions. The location of the trash rack for each experiment, i.e., whether it is at the ramp toe or the weir crest, is detailed in Section 2.2.

The fish passage at the downstream end of the flume was divided into two equal parts with outlets A and B, respectively, by placing a vertical thin board in the middle of the flume cross-section (Figure 1). The separating board extended upstream at various lengths depending on the experimental configuration. A rack was installed in one of the two downstream parts of the flume while the other part did not have any obstruction. For consistency, the rack was always placed in the part leading to outlet B (right side of the flume-Figure 2). Cases with no racks, i.e., both parts did not have any obstruction, were also tested to provide a baseline for comparison.

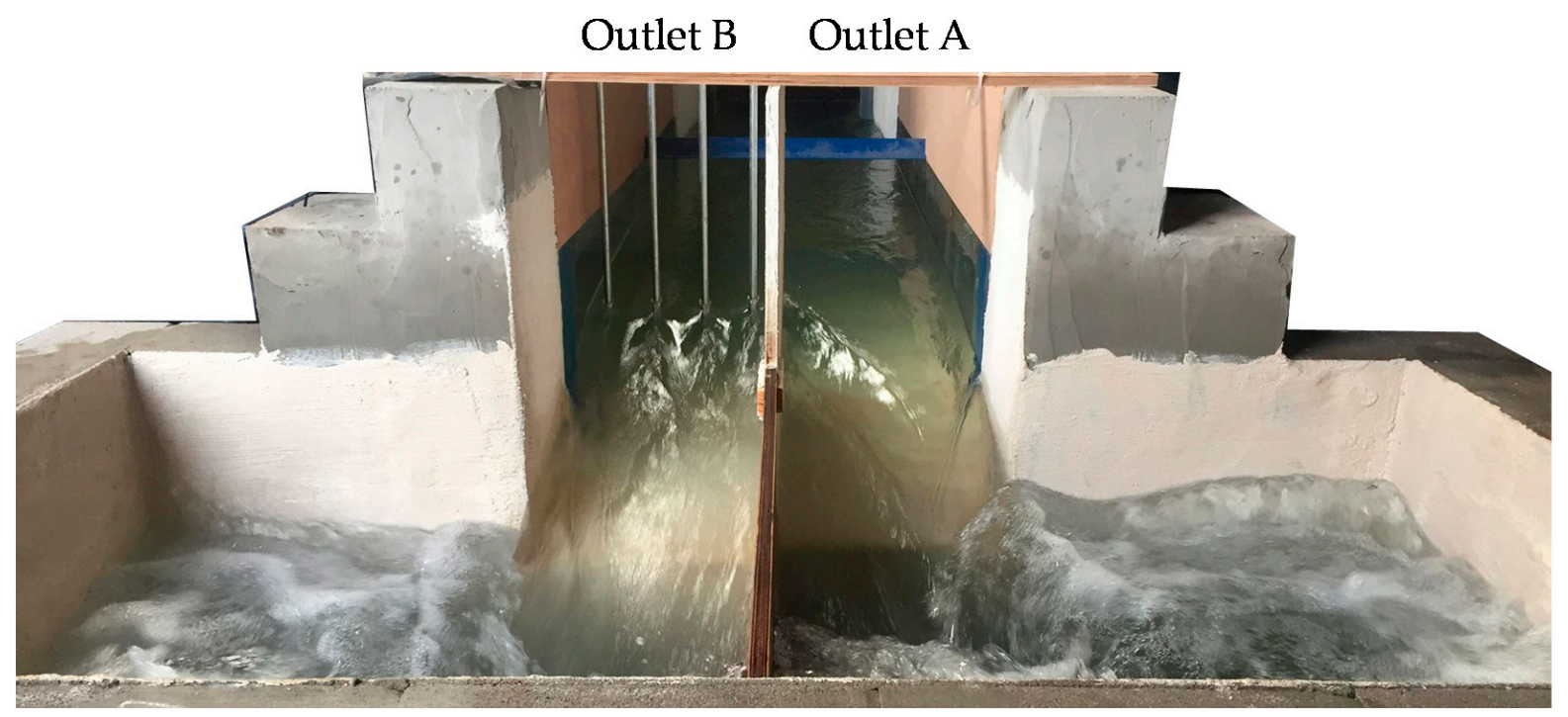

Figure 2. Downstream view of the experimental setup with downstream reservoirs, outlet $A$ and outlet B (note a rack in outlet B). Configuration of test 2 .

The flume was supplied with water from an underground $400 \mathrm{~m}^{3}$ storage tank using two pumps and two pipes. Downstream of the test facility, the water was collected in 
a free surface channel discharging in the tank through a $1 \mathrm{~m}$ high chute (closed water supply system). The tank was filled with tap water some weeks before first tests and the water was recirculated every working day to maintain dissolved oxygen concentration and prevent stagnation. The incoming flow discharge was measured with electromagnetic flowmeters (Promag 50, Endress Hauser, Brussels, Belgium) on the supply pipes, while the flow velocity at different sections of the flume was measured with a propeller (MiniWater 20, Schiltknecht Messtechnick, Gossau, Switzerland).

The downstream flume section was used for flow observation and its sidewalls were made of Perspex (Figure 3). During the experiments with fish, dark plastic sheets were placed around the transparent walls to visually isolate the flume environment from the rest of the laboratory. The sidewalls in the rest of the flume were constructed with concrete blocks with a mortar layer ensuring they were waterproof. The mortar was layered with a brush to create a rough surface.

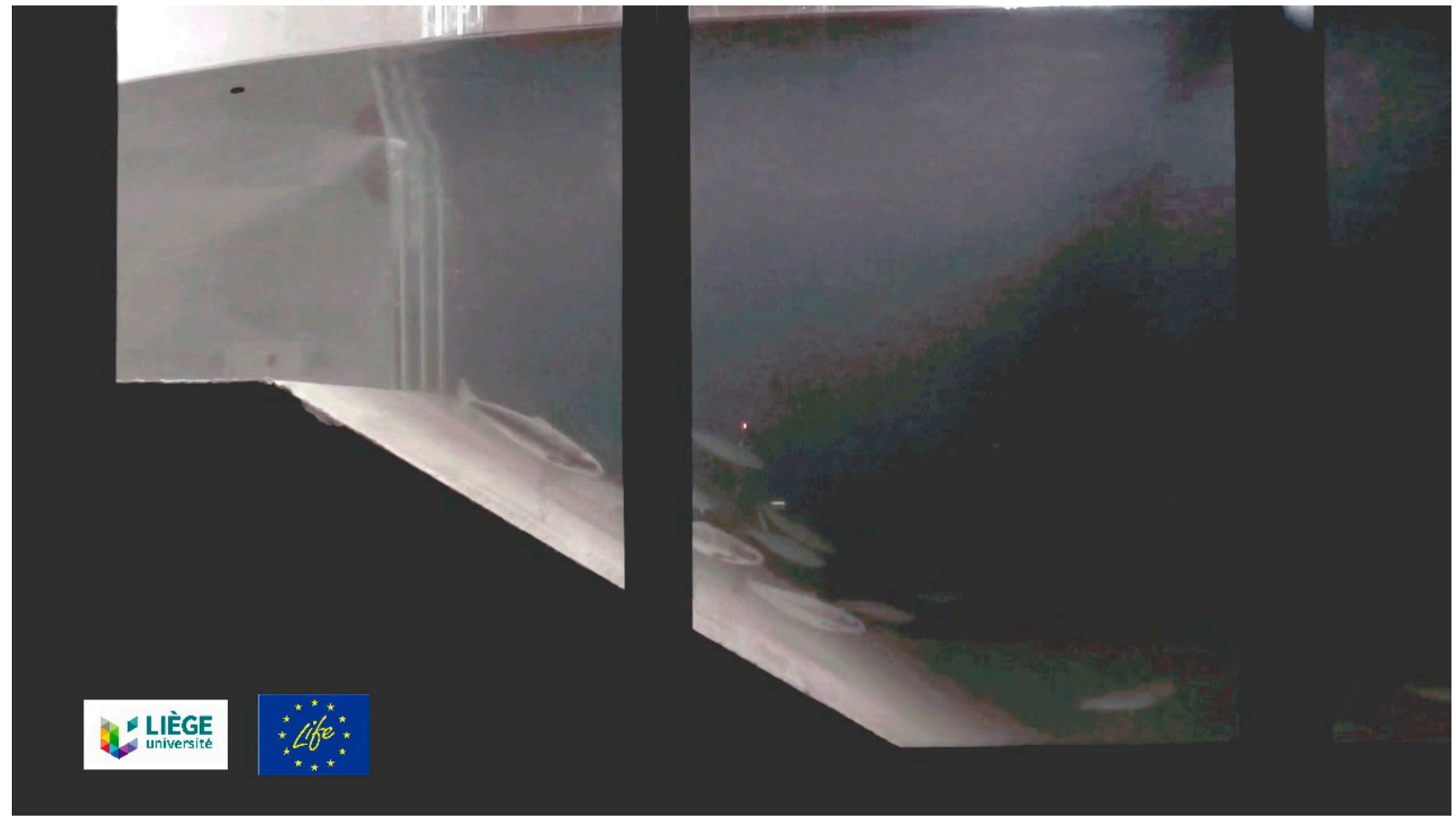

Figure 3. Smolts swimming in the flume. Configuration of test 2. Smolts swam facing the flow (positive rheotaxis) every time they went through the fish passage.

\subsection{Test Configurations}

The same steady flow was established for each experimental test and smolts were placed at the upstream part of the flume, in an acclimatization compartment (Figure 1) closed upstream by the screen wall and downstream by a movable rack. When the movable rack was opened, the fish could swim downstream and exit the flume through one of the two outlets. Separated downstream reservoirs facilitated the counting of the fish that chose each outlet and ended up in the respective reservoir (Figure 2). The flow conditions were determined by the maximum steady discharge that could be attained in the facility, which is around $0.3 \mathrm{~m}^{3} / \mathrm{s}$, leading to a depth-averaged flow velocity of $1.5 \mathrm{~m} / \mathrm{s}$ with a flow depth of $0.24 \mathrm{~m}$ in critical flow conditions at the broad-crested weir, while the flow depth upstream of the ramp leading to the weir was $1 \mathrm{~m}$ with mean flow velocity around $0.36 \mathrm{~m} / \mathrm{s}$. The downstream passage dimensions and flow parameters are close to the minimum required ones for the inlet of a downstream passage [11].

Seven experimental configurations were tested, which were differentiated by changes in the location and geometry of the trash rack and the slope of the ramp upstream of the broad-crested weir (Table 1 and Figure 4 ). The trash racks consisted of vertical round bars 
with a $15 \mathrm{~mm}$ diameter that were evenly spaced either by $10 \mathrm{~cm}$ or by $20 \mathrm{~cm}$. While the latter spacing is recommended for downstream fish passages [11], it is also considered quite large to stop floating debris that can be expected in large rivers such as the Meuse River for which these passages were tested. The trash rack was positioned either at the crest of the broad-crested weir at the flume outlet or further upstream at the toe of the inclined ramp (Figure 4), with the flow velocity in the former being significantly higher. To investigate the effect of the velocity gradient, ramp slopes of $40 \%$ and $60 \%$ were tested. The smaller slope generated a velocity gradient of $0.8 \mathrm{~m} / \mathrm{s} / \mathrm{m}$ and the steeper one a velocity gradient of $1.1 \mathrm{~m} / \mathrm{s} / \mathrm{m}$. While both values are close to the $1 \mathrm{~m} / \mathrm{s} / \mathrm{m}$ gradient recommended value [27], they induce significantly different horizontal dimensions (50\% difference) and then different design constraints.
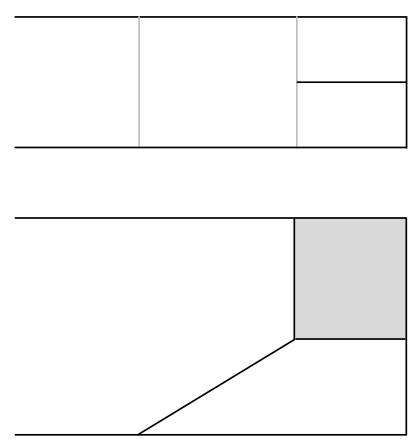

Test 1
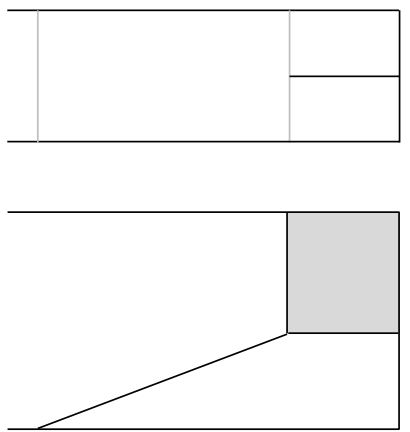

Test 3
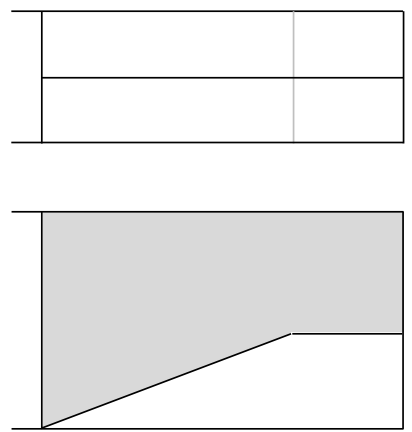

Test 6
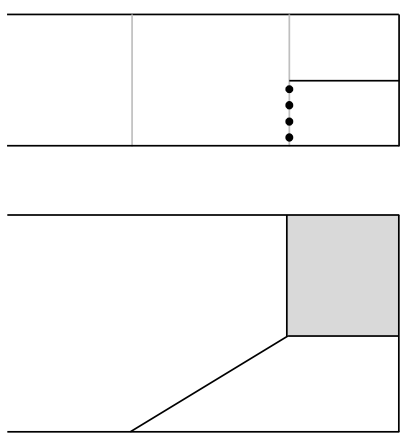

Test 2
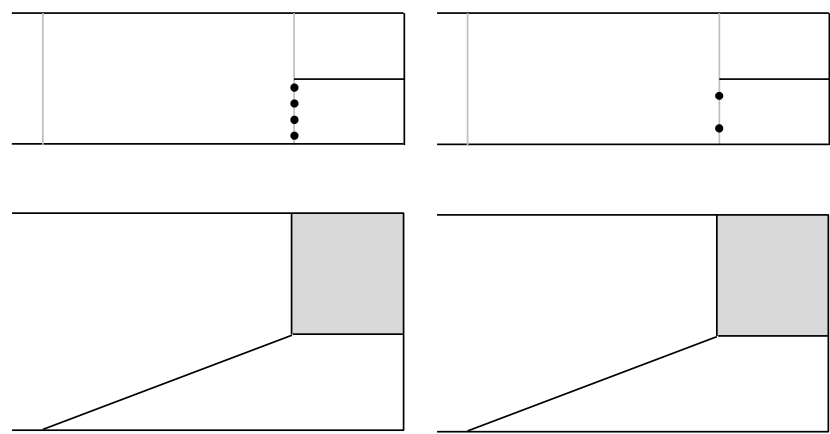

Test 4

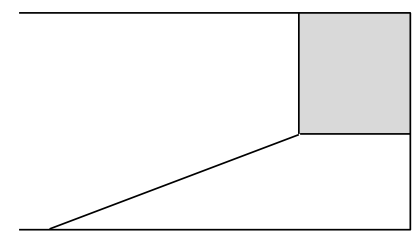

Test 5
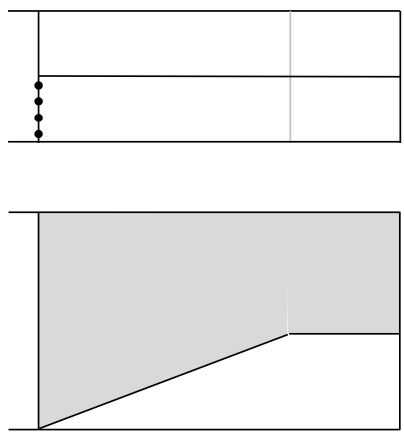

Test 7
Flow direction

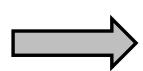

Rack bars

diameter not scaled

Figure 4. Configurations' geometry. The upper and the lower rows show plan views and side views, respectively, of the downstream end of the flume for each configuration. The thick black dots in the plan views of Configurations 2, 4, 5, and 7 show the number and position of the bars of the rack. The grey area in the side views shows the separating wall between outlets A and B. 
Table 1. Details of experimental configurations. Each configuration was tested with 2 fish batches created from a group of smolts, one group arriving to the laboratory every week. The different ramp slopes, rack bar spacings, and rack location are schematized in Figure 4.

\begin{tabular}{|c|c|c|c|c|c|c|}
\hline $\begin{array}{l}\text { Config. } \\
\text { Number }\end{array}$ & $\begin{array}{l}\text { Groups } \\
\text { Number }\end{array}$ & $\begin{array}{l}\text { Batches } \\
\text { Number }\end{array}$ & $\begin{array}{c}\text { Smolts per } \\
\text { Batch }\end{array}$ & $\begin{array}{c}\text { Slope } \\
\text { of Ramp }\end{array}$ & $\begin{array}{c}\text { Spacing of } \\
\text { Rack Bars }\end{array}$ & $\begin{array}{l}\text { Location } \\
\text { of Rack }\end{array}$ \\
\hline 1 & 2 & $2.1-2.2$ & 18 & $60 \%$ & \multicolumn{2}{|c|}{ No rack ${ }^{1}$} \\
\hline 2 & 2 & $2.3-2.4$ & 18 & $60 \%$ & $10 \mathrm{~cm}$ & Weir crest ${ }^{1}$ \\
\hline 3 & 3 & $3.1-3.2$ & 18 & $40 \%$ & \multicolumn{2}{|c|}{ No rack ${ }^{1}$} \\
\hline 4 & 3 & $3.3-3.4$ & 18 & $40 \%$ & $10 \mathrm{~cm}$ & Weir crest ${ }^{1}$ \\
\hline 5 & 4 & $4.1-4.2$ & 20 & $40 \%$ & $20 \mathrm{~cm}$ & Weir crest ${ }^{1}$ \\
\hline 6 & 4 & $4.3-4.4$ & 20 & $40 \%$ & \multicolumn{2}{|c|}{ No rack ${ }^{2}$} \\
\hline 7 & 4 & $4.5-4.6$ & 20 & $40 \%$ & $10 \mathrm{~cm}$ & Ramp toe ${ }^{2}$ \\
\hline
\end{tabular}

${ }^{1}$ The upstream extent of the wall that separates outlets A and B is at the weir crest. ${ }^{2}$ The upstream extent of the wall that separates outlets $\mathrm{A}$ and $\mathrm{B}$ is at the ramp toe.

The fact that one-year-old smolts are not available all year long [23] imposed some limitations to this study and as a result not all combinations of the different geometric configurations were tested (Table 1). Atlantic salmon smolts moving during the day have gregarious behavior [28]. For this reason and since the tests were carried out during daytime, all tests involved batches of fish rather than single individuals. To avoid bias from potential learning and adjustment of the fish behavior to a specific configuration, each batch went into the flume only once (Table 1). In addition, it was decided to test each configuration with 2 distinct batches to replicate the tests.

\subsection{Smolt Availability}

The smolts used for the experiments were provided by the Conservatoire du Saumon Mosan hatchery, where they are bred in the framework of a restocking program of the Meuse River and its main tributaries. The target group of one-year-old Atlantic salmon is available only during spring and as a result this imposed some time constraints to the experiments. A group of 72 to 120 smolts was received in the laboratory every week for four weeks. Before and after the tests, the smolts were maintained in $0.67 \mathrm{~m}^{3}$ covered PVC tanks $\left(0.45 \mathrm{~m}^{3}\right.$ of water) with a $0.14 \mathrm{~m}^{2}$ glass window on the top (12.5\% of the top surface) to allow for natural lighting. Each PVC tank was equipped with an aerator (AquaOxy 4800, Oase, Hörstel, Germany) and a recirculating pump (Nano-Stream 6045, Tunze, Penzberg, Germany) while the temperature and dissolved oxygen concentration were continuously monitored (HQ40d multimeter with MTC101 electrode, HACH, Düsseldorf, Germany) and when needed adjusted to ensure the water quality was maintained at acceptable levels. Since water temperature in breeding basins of Conservatoire du Saumon Mosan $\left(5-10^{\circ} \mathrm{C}\right)$ and in the laboratory $\left(15-17^{\circ} \mathrm{C}\right)$ was not the same, water temperature evolution was managed carefully. In particular, special care was taken to prevent smolts' exposure to a water temperature gradient above $0.5^{\circ} \mathrm{C} / \mathrm{h}$. The smolts were released to River Ourthe after the completion of the experiments.

\subsection{Experimental Protocol and Tests Methodology}

The total number of smolts used in this study was 346. Eighty-two of them (ten in group 0 and 72 in group 1) were used to test and validate the test's methodology and the remaining 264 smolts (groups 2-4) were used to test the seven different geometric configurations listed in Table 1. Each group from 1 to 4 was divided into four or six batches of 18 or 20 smolts, depending on the weekly fish availability. The batches of each group consisted of smolts with similar mass distribution regarding 3 classes defined based on the available fish mass. As an example, Table 2 presents the mass distribution of group 1. Average mass of all smolts considered in this study was $33.4 \mathrm{~g}$ (SD $6.4 \mathrm{~g}$ ) and averaged fork length was $14.7 \mathrm{~cm}(\mathrm{SD} 0.9 \mathrm{~cm})$. 
Table 2. Mass distribution in batches from group 1: $m$ denotes the fish mass.

\begin{tabular}{ccccc}
\hline Batch Number & Number of Smolts & $\mathbf{m}<\mathbf{3 0} \mathbf{g}$ & $\mathbf{3 0} \mathbf{g} \leq \mathbf{m} \leq \mathbf{4 0} \mathbf{g}$ & $\mathbf{m}>\mathbf{4 0} \mathbf{g}$ \\
\hline 1.1 & 18 & 6 & 9 & 3 \\
1.2 & 18 & 6 & 10 & 2 \\
1.3 & 18 & 6 & 10 & 2 \\
1.4 & 18 & 6 & 10 & 2 \\
\hline
\end{tabular}

A preliminary observation test with ten smolts (group 0) was carried out just before the arrival of group 1. The aim of this preliminary test was to ensure that the smolts can survive in the laboratory for at least one week and to confirm that the smolts swim downstream in the flume, both during daytime and nighttime. Smolts of group 1 were then used to improve the test's protocol. Each of the four batches of the group 1 was placed in the flume separately. These preliminary tests helped to realize that the fish that were put in the acclimatization compartment became calm within $10 \mathrm{~min}$ and thus the movable rack was opened after this period of time. A gregarious behavior of smolts was confirmed in the flume for all batches as several smolts usually swam downstream and exited the flume through one of the outlets together. It was also observed that the time needed for the fish to exit the flume through one of the outlets varied significantly and ranged from one to more than four hours.

Following these preliminary tests and in an attempt to minimize the effect on outlet selection of parameters not controlled in the study, such as lighting, it was decided to test the two batches of smolts for each experimental configuration during daytime, one in the morning and one in the afternoon. The total duration of each test was maximum four hours after which the remaining smolts in the flume were forced to exit the flume. To prevent mortality of the fish in the downstream reservoirs due to high energy dissipation rate, it was decided to reduce the water discharge every $30 \mathrm{~min}$ during the time needed to remove the fish from the reservoirs (around $5 \mathrm{~min}$ ). It was observed that more fish swam through the outlets with this variation in discharge $(76 \%$ on average- batch $1.4+$ batches of groups 2 to 4 ) compared to a continuous period with the same high discharge ( $33 \%$ on average-batches 1.1,1.2 and 1.3).

The experimental protocol for smolt groups $2-4$ (14 batches) consisted of the following steps:

1. Placement of a batch of smolts in the acclimatization compartment of the flume for 10 min.

2. Opening of the movable rack to allow the smolts to swim downstream and establishment of a steady water discharge of $0.265 \mathrm{~m}^{3} / \mathrm{s}$ for $30 \mathrm{~min}$.

3. Lowering of the water discharge to $0.116 \mathrm{~m}^{3} / \mathrm{s}$, counting and removal of the fish that swam through one of the outlets and ended up in the downstream reservoirs. This operation lasted around $5 \mathrm{~min}$, depending on the number of smolts to catch in the reservoirs.

4. Set the water discharge back to $0.265 \mathrm{~m}^{3} / \mathrm{s}$ for another $30 \mathrm{~min}$.

5. Repetition of steps 3 and 4 for three more times.

6. In case smolts swam through one of the outlets during the fifth 30 min period with $0.265 \mathrm{~m}^{3} / \mathrm{s}$ discharge, steps 3 and 4 were repeated for two more times and after that the test ended. In case no smolts swam through one of the outlets during the fifth $30 \mathrm{~min}$ period with $0.265 \mathrm{~m}^{3} / \mathrm{s}$ discharge, this period was extended by 30 more minutes and subsequently the test was over.

7. Removal of the fish from the downstream reservoir and counting. The fish that were still in the flume were forced, using a brush, to swim downstream and choose one of the two outlets. Removal of these fish from the downstream reservoirs and counting. 
Flow direction
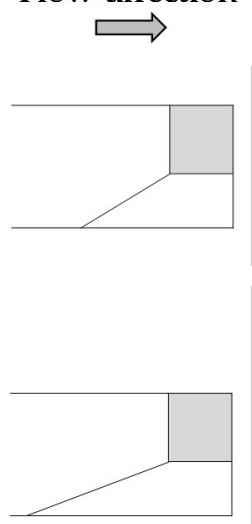

Config. 4

Config. 5

Config. 6

Config. 7

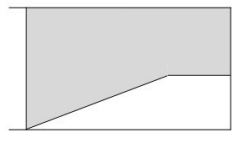

\section{Results}

It was observed during the tests that some fish were able to get back in the flume after crossing over the broad-crested weir. Despite camera footage being used to observe and quantify this behavior, only the smolts trapped in the reservoirs are considered in the following results.

Table 3 and Figure 5 detail the number and the percentage of smolts that exited the flume through each outlet within the test duration (unforced) or being forced to pass at the end of each test (forced). Since two smolt batches were tested with each geometric configuration, the results are analyzed in the following as the sum of the results from each batch.
Outlet B

Config. 1
Config. 2
Config. 4
Config. 3
$\left[\begin{array}{l}\text { Config. } 5 \\ \text { Config. } 6\end{array}\right.$

Outlet A

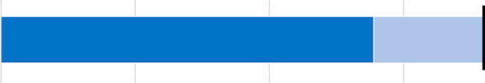

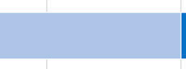
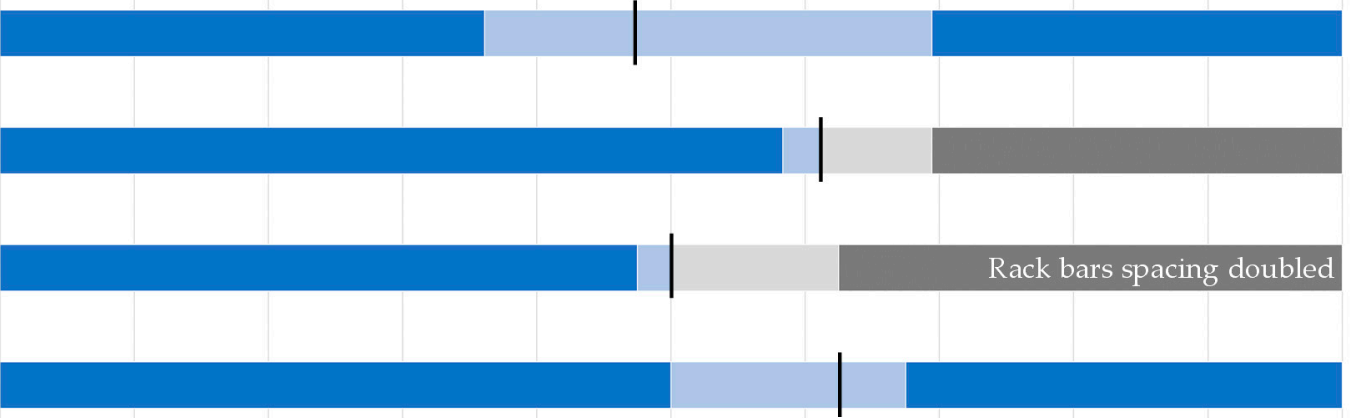

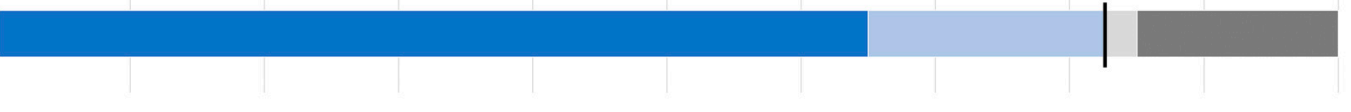

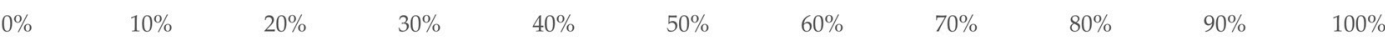

No rack bars

Unforced
Forced
With rack bars

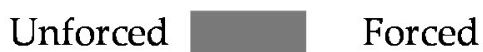

Figure 5. Smolt passages repartition for each configuration between outlets A and B and for fish swimming downstream within the test duration (unforced) or being forced to pass at the end of test (forced). Black vertical lines show the separation between outlet A and B choice. Details about the experimental setup are given in Table 1 and Figure 4.

Before reporting the effect of specific geometric configurations, the reference cases (Configurations 1, 3, and 6) are firstly analyzed. In these tests, none of the two outlets had a rack and their geometry was the same. The only difference between tests was the ramp slope (60\% for Configuration 1 and $40 \%$ for Configurations 3 and 6) and the separating wall length (short for Configurations 1 and 3 and long for Configuration 6). Figure 5 and Table 3 show that there is no perfect symmetry between the two outlets selection for the three reference cases when they are considered separately. However, when all the data for these three cases are aggregated, there is a balance with 43 smolts (38.4\%) choosing outlet A and 42 smolts (37.5\%) choosing outlet B without being forced. On the contrary, when a rack was placed in outlet $B$ (i.e., Configurations 2, 4, 5, and 7), 85 smolts (55,9\%) chose to exit the flume through the unobstructed outlet A and only $43(28,3 \%)$ selected the outlet B with the rack. 
Table 3. Numbers of smolts per batch going through outlet A or B within the experimental duration or when forced to swim downstream four hours after the experiment started. The experimental configurations are described in Figures 1 and 4 . When there is a rack in the flume, it is always placed in outlet $\mathrm{B}$, while outlet $\mathrm{A}$ is unobstructed for all configurations.

\begin{tabular}{|c|c|c|c|c|c|c|}
\hline $\begin{array}{l}\text { Config. } \\
\text { Number }\end{array}$ & $\begin{array}{c}\text { Batch } \\
\text { Number }\end{array}$ & $\begin{array}{c}\text { Number of } \\
\text { Smolts in Batch }\end{array}$ & $\begin{array}{c}\text { Smolts in Outlet A } \\
\text { within the } \\
\text { Test Duration }\end{array}$ & $\begin{array}{c}\text { Smolts in Outlet B } \\
\text { within the } \\
\text { Test Duration }\end{array}$ & $\begin{array}{l}\text { Smolts in Outlet } \\
\text { A when Forced }\end{array}$ & $\begin{array}{l}\text { Smolts in Outlet } \\
\text { B when Forced }\end{array}$ \\
\hline \multirow{2}{*}{1} & 2.1 & 18 & 7 & 8 & 1 & 2 \\
\hline & 2.2 & 18 & 3 & 10 & 2 & 3 \\
\hline \multirow{2}{*}{2} & 2.3 & 18 & 12 & 5 & 1 & 0 \\
\hline & 2.4 & 18 & 7 & 6 & 3 & 2 \\
\hline \multirow{2}{*}{3} & 3.1 & 18 & 8 & 3 & 2 & 5 \\
\hline & 3.2 & 18 & 5 & 8 & 2 & 3 \\
\hline \multirow{2}{*}{4} & 3.3 & 18 & 13 & 2 & 1 & 2 \\
\hline & 3.4 & 18 & 8 & 9 & 0 & 1 \\
\hline \multirow{2}{*}{5} & 4.1 & 20 & 9 & 10 & 0 & 1 \\
\hline & 4.2 & 20 & 10 & 5 & 1 & 4 \\
\hline \multirow[b]{2}{*}{6} & 4.3 & 20 & 10 & 8 & 2 & 0 \\
\hline & 4.4 & 20 & 10 & 5 & 3 & 2 \\
\hline \multirow[b]{2}{*}{7} & 4.5 & 20 & 17 & 1 & 2 & 0 \\
\hline & 4.6 & 20 & 9 & 5 & 5 & 1 \\
\hline
\end{tabular}

Table 3 also shows that for every configuration, not all smolts exited the flume within four hours. On average 19.4\% (SD 6.6\%) had to be forced to exit the flume after four hours passed. It is, however, interesting to notice that, except for Configuration 3 that shows the highest proportion of fish to be forced (33\%), considering the "forced" fish in the analysis did not change the preferred outlet in each configuration.

The only difference between Configurations 1 and 3 was the ramp slope, $60 \%$ and $40 \%$, respectively, with the separating wall extending along the weir crest only. It is the same for Configurations 2 and 4, respectively, which in addition both had a rack with $10 \mathrm{~cm}$ bar spacing at the weir crest in outlet B. While 28 smolts $(77.8 \%)$ exited the flume through either of the unobstructed outlets with Configuration 1, only $24(66.7 \%)$ did so with Configuration 3. On the contrary, a higher fraction of the smolts (32 fish-88.9\%) exited the flume without being forced with Configuration 4 compared to Configuration 2 (30 fish-83.3\%). Interestingly, increasing the separating wall to the ramp toe at constant ramp slope and without a rack (Configurations 3 and 6) increased (from 66.7 to $82.5 \%$ ) the percentage of fish exiting the flume while not being forced. It was the contrary when a rack was added at the extremity of the separating wall, since $88.9 \%$ of the smolts exited the flume without being forced with Configuration 4 (short wall), while only $80 \%$ did so in Configuration 7 with a long wall.

The effect of bar spacing can be assessed by comparing Configurations 4 and 5, which had the same ramp slope of $40 \%$ and a rack at the weir crest with bar spacing of $10 \mathrm{~cm}$ and $20 \mathrm{~cm}$, respectively. With a bar spacing of $10 \mathrm{~cm}, 11$ smolts $(30.6 \%)$ exited the flume through the outlet equipped with a rack, while $15(37.5 \%)$ did so when the bar spacing was $20 \mathrm{~cm}$. In the former case, 21 smolts (58.3\%) exited the flume through the unobstructed outlet B, while $19(47.5 \%)$ did so in the latter configuration.

For the experimental setup with a $40 \%$ slope ramp and a rack with $10 \mathrm{~cm}$ bar spacing, the placement of the rack at the ramp toe (Configuration 7) compared to the weir crest (Configuration 4) made the percentage of smolts exiting the flume through the rack decrease from 30.6 to $15 \%$. In the meantime, the percentage of smolts exiting the flume through the unobstructed outlet A increased from 58.3 to $65 \%$.

\section{Discussion}

This study focused on the effect on Atlantic salmon smolts' outlet selection of some specific geometric parameters of a downstream fish passage. Smolts had only three so- 
lutions when placed in the experimental flume, in which flow conditions were the same for all tests except at the outlets: either stay in the flume or exit it through one of the two outlets. Once the tests started, smolts moved actively downstream to the fish passage, in groups and faced downstream (negative rheotaxis). They switched to positive rheotaxis and swam against the current once they entered the velocity acceleration area (ramp). Similar behavior was observed with Pacific salmonid smolts approaching weir crest in a laboratory flume [24] but also in the field with Atlantic salmon smolts [14]. In this respect, none of the outlets could be seen as "attractive". This is consistent with the fact that downstream migrating fish tend to avoid areas with higher velocity gradients [23]. In this study, however, the fish had no other choice but to go through a 0.8 to $1.1 \mathrm{~m} / \mathrm{s} / \mathrm{m}$ velocity gradient to exit the flume and continue their way downstream. Downstream movement in the flume was active, with smolts maintaining over the ramp and moving transversally in front of both outlets before exiting the flume through one of them. Some smolts rejected the outlet they initially selected by actively swimming back upstream in the flume. Such active displacement has been documented with Pacific salmon smolts in a laboratory flume [24-26] and is likely to provide greater control to select the most preferred, or "less bad" way of passage [14,24-26].

The tests presented in this paper were performed during daytime. All the results show that a smaller proportion of smolts exited the flume through an outlet equipped with a trash rack compared to the same outlet without a rack. This supports the idea that fish respond to visual cues [24] and tend to avoid areas showing obstacles. The repetition of similar tests during nighttime or with different lighting conditions is needed to prove this latter assumption since lighting influence fish behavior close to obstacles [24,29]. The fact that two times fewer smolts exited the flume through the rack located in the lower velocity area (Configuration 7) compared to the same rack located in the higher velocity area (Configuration 4) suggests that hydrodynamic conditions may alter the fish ability to make a choice based on visual cues. Results also suggest that bars spacing in the order of fish length has a repelling effect, even if the repelling effect is much less than the one of classical bars interplay for guidance racks [11].

This study considered tests realized with smolt batches, and consequently the gregarious behavior of the fish [28] influenced the results since once one smolt went through an outlet, several others usually followed. Only aggregated results at the batch scale were collected. This prevents finer analysis, for instance at the scale of individuals such as in [24-26], that is required to go deeper into the understanding of fish behavior [23].

\section{Conclusions}

This study analyzed experimentally the response of Atlantic salmon smolts to varied geometries of the entrance of a downstream passage for downstream migration. The experiments were conducted at 1:1 scale in a laboratory flume, the downstream end of which was split into two outlets, during daytime and considering smolt batches. One outlet was equipped with different configurations of a trash rack with vertical round bars protecting the downstream passage from floating debris and the other outlet was always unobstructed.

Results showed that in general less smolts exit the flume through the outlet equipped with a trash rack compared to the same outlet without a rack. When comparing the different trash rack geometries that were tested, the narrower bars spacing of $10 \mathrm{~cm}$ has more of a repelling effect than the $20 \mathrm{~cm}$ spacing. A rack placed in the low-velocity zone at the toe of the outlet acceleration ramp has more impact compared to being placed in the high-velocity zone at the weir crest.

While experiments with live fish are useful to observe their swimming behavior, the number of available fish is typically limited. As a result, more repetition tests are needed to corroborate the findings of this study. Such tests were not possible in this study due to the short seasonal availability of Atlantic salmon smolts. In addition, complementary studies with more detailed observations at individual scale and more comprehensive 
measurements of the flow field features at the entrance of fish passages like those presented in this study can provide the information needed to examine potential correlations with the observed fish behavior.

The information gathered in this study was used in the design of a downstream passage at Grands Malades hydropower plant on the Meuse River, the attractivity of which will be evaluated on site using tagged smolts and ultrasonic telemetry.

Author Contributions: Conceptualization, S.E., P.A., B.D. and M.P.; methodology, S.E., P.A. and B.D.; formal analysis, S.E. and V.K.; writing-original draft preparation, V.K., S.E. and B.D.; writingreview and editing, V.K. and S.E.; supervision, S.E. and M.P. All authors have read and agreed to the published version of the manuscript.

Funding: This work was funded by the European Union LIFE program LIFE4FISH (LIFE16/NAT/ $\mathrm{BE} / 000807)$.

Institutional Review Board Statement: Ethics committee of Liege University judged that our study was only observation, i.e., not an interventionary study (ULiege Commission d'Ethique AnimaleDossier no: 18-2086).

Data Availability Statement: The data presented in this study are available in the Life4Fish project reports on https: / /www.life4fish.be/fr (last accessed on 28 December 2021) or on reasonable request to the corresponding author.

Acknowledgments: The authors acknowledge the Service Public de Wallonie-Conservatoire du Saumon Mason for providing the smolts and the ProFish company for its support. Master student A. Delbrouck is acknowledged for his help in performing some of the experiments and for preliminary data analysis.

Conflicts of Interest: The authors declare no conflict of interest. The funders had no role in the design of the study; in the collection, analyses, or interpretation of data; in the writing of the manuscript, or in the decision to publish the results.

\section{References}

1. Kitsikoudis, V.; Becker, B.P.J.; Huismans, Y.; Archambeau, P.; Erpicum, S.; Pirotton, M.; Dewals, B. Discrepancies in Flood Modelling Approaches in Transboundary River Systems: Legacy of the Past or Well-grounded Choices? Water Resour. Manag. 2020, 34, 3465-3478. [CrossRef]

2. Poff, N.L.; Olden, J.; Merritt, D.M.; Pepin, D.M. Homogenization of regional river dynamics by dams and global biodiversity implications. Proc. Natl. Acad. Sci. USA 2007, 104, 5732-5737. [CrossRef] [PubMed]

3. Liermann, C.R.; Nilsson, C.; Robertson, J.; Ng, R.Y. Implications of Dam Obstruction for Global Freshwater Fish Diversity. Biosci. 2012, 62, 539-548. [CrossRef]

4. Vörösmarty, C.J.; McIntyre, P.B.; Gessner, M.O.; Dudgeon, D.; Prusevich, A.; Green, P.; Glidden, S.; Bunn, S.E.; Sullivan, C.A.; Liermann, C.R.; et al. Global threats to human water security and river biodiversity. Nature 2010, 467, 555-561. [CrossRef] [PubMed]

5. Katopodis, C.; Williams, J.G. The development of fish passage research in a historical context. Ecol. Eng. 2012, 48, 8-18. [CrossRef]

6. Noonan, M.J.; A Grant, J.W.; Jackson, C.D. A quantitative assessment of fish passage efficiency. Fish Fish. 2012, 13, 450-464. [CrossRef]

7. Silva, A.T.; Lucas, M.C.; Castro-Santos, T.; Katopodis, C.; Baumgartner, L.; Thiem, J.; Aarestrup, K.; Pompeu, P.S.; O’Brien, G.; Braun, D.C.; et al. The future of fish passage science, engineering, and practice. Fish Fish. 2018, 19, 340-362. [CrossRef]

8. Thorstad, E.B.; Whoriskey, F.; Uglem, I.; Moore, A.; Rikardsen, A.H.; Finstad, B. A critical life stage of the Atlantic salmon Salmo salar: Behaviour and survival during the smolt and initial post-smolt migration. J. Fish Biol. 2012, 81, 500-542. [CrossRef]

9. Renardy, S.; Takriet, A.; Benitez, J.-P.; Dierckx, A.; Baeyens, R.; Coeck, J.; Pauwels, I.S.; Mouton, A.; Archambeau, P.; Dewals, B.; et al. Trying to choose the less bad route: Individual migratory behaviour of Atlantic salmon smolts (Salmo salar L.) approaching a bifurcation between a hydropower station and a navigation canal. Ecol. Eng. 2021, 169, 106304. [CrossRef]

10. Ovidio, M.; Renardy, S.; Dierckx, A.; Matondo, B.N.; Benitez, J.-P. Improving bypass performance and passage success of Atlantic salmon smolts at an old fish-hostile hydroelectric power station: A challenging task. Ecol. Eng. 2021, 160, 106148. [CrossRef]

11. Larinier, M.; Travade, F. Downstream migration: Problems and facilities. Bull. Français Pêche Piscic. 2002, 364, 181-207. [CrossRef]

12. Nyqvist, D.; McCormick, S.D.; Greenberg, L.; Ardren, W.R.; Bergman, E.; Calles, O.; Castro-Santos, T. Downstream Migration and Multiple Dam Passage by Atlantic Salmon Smolts. N. Am. J. Fish. Manag. 2017, 37, 816-828. [CrossRef]

13. Szabo-Meszaros, M.; Silva, A.; Bærum, K.; Baktoft, H.; Alfredsen, K.; Hedger, R.; Økland, F.; Gjelland, K.; Fjeldstad, H.-P.; Calles, O.; et al. Validation of a Swimming Direction Model for the Downstream Migration of Atlantic Salmon Smolts. Water 2021, 13, 1230. [CrossRef] 
14. Ovidio, M.; Dierckx, A.; Bunel, S.; Grandry, L.; Spronck, C.; Benitez, J. Poor Performance of a Retrofitted Downstream Bypass Revealed by the Analysis of Approaching Behaviour in Combination with a Trapping System. River Res. Appl. 2017, 33, 27-36. [CrossRef]

15. Calles, O.; Karlsson, S.; Hebrand, M.; Comoglio, C. Evaluating technical improvements for downstream migrating diadromous fish at a hydroelectric plant. Ecol. Eng. 2012, 48, 30-37. [CrossRef]

16. Williams, J.G. Mitigating the effects of high-head dams on the Columbia River, USA: Experience from the trenches. Hydrobiologia 2008, 609, 241-251. [CrossRef]

17. Harbicht, A.B.; Watz, J.; Nyqvist, D.; Virmaja, T.; Carlsson, N.; Aldvén, D.; Nilsson, P.A.; Calles, O. Guiding migrating salmonid smolts: Experimentally assessing the performance of angled and inclined screens with varying gap widths. Ecol. Eng. 2022, 174, 106438. [CrossRef]

18. Greenberg, L.; Calles, O.; Andersson, J.; Engqvist, T. Effect of trash diverters and overhead cover on downstream migrating brown trout smolts. Ecol. Eng. 2012, 48, 25-29. [CrossRef]

19. Albayrak, I.; Boes, R.M.; Kriewitz-Byun, C.R.; Peter, A.; Tullis, B.P. Fish guidance structures: Hydraulic performance and fish guidance efficiencies. J. Ecohydraulics 2020, 5, 113-131. [CrossRef]

20. Beck, C.; Albayrak, I.; Meister, J.; Peter, A.; Selz, O.M.; Leuch, C.; Vetsch, D.F.; Boes, R.M. Swimming Behavior of Downstream Moving Fish at Innovative Curved-Bar Rack Bypass Systems for Fish Protection at Water Intakes. Water 2020, 12, 3244. [CrossRef]

21. Leander, J.; Klaminder, J.; Hellström, G.; Jonsson, M. Bubble barriers to guide downstream migrating Atlantic salmon (Salmo salar): An evaluation using acoustic telemetry. Ecol. Eng. 2021, 160, 106141. [CrossRef]

22. Vowles, A.S.; Kemp, P.S. Effects of light on the behaviour of brown trout (Salmo trutta) encountering accelerating flow: Application to downstream fish passage. Ecol. Eng. 2012, 47, 247-253. [CrossRef]

23. Williams, J.G.; Armstrong, G.; Katopodis, C.; Larinier, M.; Travade, F. Thinking like a fish: A key ingredient for development of effective fish passage facilities at river obstructions. River Res. Appl. 2012, 28, 407-417. [CrossRef]

24. Kemp, P.S.; Gessel, M.H.; Sandford, B.P.; Williams, J.G. The behaviour of Pacific salmonid smolts during passage over two experimental weirs under light and dark conditions. River Res. Appl. 2006, 22, 429-440. [CrossRef]

25. Enders, E.C.; Gessel, M.H.; Williams, J.G. Development of successful fish pasage structures for downstream migrants requires knowledge of their behavioural response to accelerating flow. Can. J. Fish. Aquat. Sci. 2009, 66, 2109-2117. [CrossRef]

26. Kemp, P.S.; Gessel, M.H.; Williams, J.G. Fine-Scale Behavioral Responses of Pacific Salmonid Smolts as They Encounter Divergence and Acceleration of Flow. Trans. Am. Fish. Soc. 2005, 134, 390-398. [CrossRef]

27. Courret, D.; Larinier, M. Guide Pour la Conception de Prises d'eau "Ichtyocompatibles" Pour les Petites Centrales Hydroélectriques; Rapport GHAAPPE RA.08.04. November, 2008; ONEMA: Vincennes, France, 2008.

28. Riley, W.D.; Ibbotson, A.T.; Maxwell, D.L.; Davison, P.I.; Beaumont, W.R.C.; Ives, M.J. Development of schooling behaviour during the downstream migration of Atlantic salmon Salmo salar smolts in a chalk stream. J. Fish Biol. 2014, 85, 1042-1059. [CrossRef]

29. Vowles, A.S.; Anderson, J.J.; Gessel, M.H.; Williams, J.G.; Kemp, P.S. Effects of avoidance behaviour on downstream fish passage through areas of accelerating flow when light and dark. Anim. Behav. 2014, 92, 101-109. [CrossRef] 